\begin{tabular}{|c|c|c|c|c|}
\hline JURNAL & \multirow{2}{*}{ VOLUME 1 } & \multirow{2}{*}{ NOMOR 2 } & HALAMAN 70-141 & $\begin{array}{l}\text { ISSN 2655-8823 }(p) \\
\text { ISSN 2656-1786 }(e)\end{array}$ \\
KOLABORASI RESOLUSI KONFLIK & H
\end{tabular}

\title{
RESOLUSI KONFLIK AGRARIA BERBASIS KOMUNITAS PADA MASYARAKAT PETANI DI DESA GENTENG KECAMATAN SUKASARI KEBUPATEN SUMEDANG
}

\author{
Soni Akhmad Nulhaqim, Muhammad Fedryansyah, Eva Nuriyah Hidayat \\ Departemen Kesejahteraan Sosial FISIP UNPAD \\ Pusat Studi Konflik dan Resolusi Konflik FISIP UNPAD \\ E-mail: soni.nulhaqim@unpad.ac.id
}

\begin{abstract}
ABSTRAK
Konflik merupakan salah satu fenomena yang selalu terjadi pada masyarakat. Salah satu fenomena konflik yaitu konflik agraria pada masyarakat petani yang terjadi di Desa Genteng Kecamatan Sukasari Kabupaten Sumedang. Berbagai upaya resolusi konflik dilakukan oleh berbagai pihak untuk mengatasi konflik agraria ini. Salah satunya yaitu resolusi konflik berbasis komunitas. Artikel ini bertujuan untuk mendeskripsikan resolusi konflik agraria berbasis komunitas pada masyarakat petani di Desa Genteng berdasarkan pandangan tiga ahli yaitu masyarakat lokal Desa Genteng, praktisi pertanahan dan akademisi. Metode yang digunakan dalam penelitian ini yaitu metode kualitatif deskriptif dengan teknik pengumpulan data menggunakan teknik diskusi publik antara ketiga ahli tersebut. Berdasarkan pandangan masyarakat lokal Terjadi mis komunikasi antar warga Desa Genteng dengan pihak Perum Perhutani dalam pemanfaatan lahan. Alih fungsi lahan hutan yang terjadi di Kawasan Manglayang Timur mendorong masyarakat Desa Genteng juga beralih profesi. Dalam upaya resolusi konflik, LMDH (Lembaga Masyarakat Desa Hutan) memiliki peran yang sangat penting yaitu sebagai penengah antara petani dengan Perum Perhutani. Mediasi yang dilakukan oleh LMDH menghasilkan sebuah konsensus baru yaitu Perhutani memperbolehkan petani lokal untuk menggarap kembali lahan di kawasan hutan, namun dengan jenis tanaman tertentu yang telah ditentukan oleh Perum Perhutani. Berdasarkan pandangan ahli pertanahan dalam upaya meminimalisir konflik agraria, BPN Kabupaten Sumedang melakukan upaya sertifikasi tanah dan redistribusi tanah terutama di wilayah rawan konflik agraria yaitu di lokasi pembangunan bendungan Jatigede, dan lokasi pembangunan tol Cisumdawu. Berdasarkan pandangan akademisi masalah yang terjadi di Desa Genteng tidak hanya sekedar konflik pemanfaatan lahan saja, namun juga lebih kompleks dari itu seperti pengelolaan air PDAM, potensi kehilangan pekerjaan, konflik lahan, kemiskinan, kesadaran dalam pelestarian lingkungan, kesulitan pemasaran hasil pertanian. Upaya pemecahan masalah di Desa Genteng telah dilakukan oleh berbagai pihak yang dilakukan melalui upaya hukum preventif dan represif, pembentukan konsensus baru, pembentukan integrasi sosial dan kerjasama dengan perguruan tinggi melalui program pengabdian kepada masyarakat. Upaya penyelesaian konflik dan pemecahan masalah yang ada di Desa Genteng salah satunya dapat dilakukan melalui pemberdayaan masyarakat.
\end{abstract}

Kata kunci: konflik agraria, resolusi konflik, resolusi konflik berbasis komunitas.

\section{PENDAHULUAN}

Tidak dapat dipungkiri bahwa dalam kehidupan bermasyarakat tidak terlepas dari konflik. Konflik terjadi sebagai bagian dari perubahan sosial di masyarakat. Teori konflik Dahrendrof melihat bahwa masyarakat setiap saat tunduk pada proses perubahan, pertikaian dan konflik akan selalu terjadi dalam sistem sosial serta berbagai elemen kemasyarakatan menyumbang terhadap disintegrasi dan perubahan tersebut (Ritzer \& Douglas, 2010). Teori tersebut menunjukkan bahwa konflik merupakan realitas yang tidak dapat dihindarkan dan akan terus terjadi dalam kehidupan bermasyarakat (Nasikun dalam Nulhaqim, 2017:76).

Sebagai bagian dari perubahan sosial, konflik pada dasarnya juga merupakan salah satu cara untuk membentuk sebuah keteraturan sosial/konsensus di masyarakat. Keteraturan yang terdapat dalam masyarakat ini sering kali berasal dari pemaksaan yang dilakukan oleh pemegang kekuasaan terhadap anggotanya yang berada dibawah dengan menekankan pada peran kekuasaan dalam mempertahankan ketertiban dalam masyarakat. Hal ini menunjukkan bahwa masyarakat terbentuk dengan adanya 


\begin{tabular}{|c|c|c|c|c|}
\hline JURNAL & \multirow{2}{*}{ VOLUME 1 } & NOMOR 2 & HALAMAN 70-141 & $\begin{array}{l}\text { ISSN 2655-8823 }(p) \\
\text { ISSN 2656-1786 }(e)\end{array}$ \\
\hline KOLABORASI RESOLUSI KONFLIK & H
\end{tabular}

konsensus dan konflik menjadi persyaratan satu sama lain.

Menurut De Dreu dan Gelfand (2007) dalam Putra (2013:1) konflik merupakan proses yang mulai ketika individu atau kelompok mempersepsi terjadinya perbedaan atau oposisi antara dirinya dengan individu atau kelompok lain mengenai minat dan sumber daya, keyakinan, nilai, atau praktik-praktik lainnya. Berdasarkan definisi mengenai konflik ini, dapat dipahami bahwa konflik terjadi baik pada tataran individu maupun tataran kelompok dalam masyarakat (Putra, 2014).

Menurut Pasal 1 butir 1 UU No. 7 Tahun 2012 tentang Penanganan Konflik Sosial, dijelaskan bahwa yang dimaksud dengan konflik sosial yaitu perseteruan dan/atau benturan fisik dengan kekerasan antara dua kelompok masyarakat atau lebih yang berlangsung dalam waktu tertentu dan berdampak luas yang mengakibatkan ketidaknyamanan dan disintegrasi sosial sehingga mengganggu stabilitas nasional dan menghambat pembangunan nasional.

Konflik yang terjadi di masyarakat dapat bersifat manifest maupun bersifat laten (Dahrendrof, 1956: 173). Konflik bersifat laten yaitu apabila bentuk kepentingan-kepentingan yang terjadi tidak atau belum disadari oleh individu ataupun kelompok yang sedang terlibat konflik. Hal ini menunjukkan bahwa terdapat masyarakat yang sedang berada dalam situasi konflik namun masyarakat tersebut tidak merasa bahwa mereka sedang mengalami konflik. Sedangkan konflik manifest yaitu ketika bentuk konflik kepentingan yang terjadi telah disadari oleh individu maupun kelompok yang berkonflik atau "sedang berkonflik".

Salah satu jenis konflik yang terjadi di masyarakat yaitu konflik agraria. Konflik agrarian merupakan salah satu bentuk konflik yang berkaitan dengan tanah. Pada dasarnya tanah adalah aset yang paling penting dalam kehidupan masyarakat karena tanah adalah sumber kehidupan. Dalam negara agraris tanah merupakan sumber utama dalam berproduksi sehingga di Indonesia dalam hak kepemilikan, hak guna usaha, hak pakai, hak sewa, hak membuka tanah, hak memungut hasil hutan dibatasi dalam Undang-Undang Pokok Agraria. Permasalahan mengenai pertanahan bisa menimbulkan konflik yang berkepanjangan antara orang dengan orang maupun orang dengan badan hukum.

Berdasarkan catatan Konsorsium Pembaruan Agraria (KPA) Tahun 2017 dalam kurun waktu 2017, KPA mencatat sedikitnya telah terjadi 659 kejadian konflik agraria di berbagai wilayah di Indonesia dengan luasan 520.491,87 hektar. Konflik-konflik tersebut melibatkan sedikitnya 652.738 Kepala Keluarga (KK). Dibanding tahun 2016, angka kejadian konflik pada tahun ini menunjukkan kenaikan yang sangat siginifikan di mana terjadi peningkatan hingga $50 \%$. Jika dirata-rata, hampir dua konflik agraria terjadi dalam satu hari di Indonesia sepanjang tahun 2017. KPA (2017) juga mencatat konflik Agraria ini terjadi dalam beberapa sektor mulai dari sektor perkebunan, properti, infrastruktur, pertanian, kehutanan, pesisir/kelautan dan pertambangan.

Salah satu konflik agraria yang pernah terjadi yaitu konflik agraria antara masyarakat petani dengan Perum Perhutani di Desa Genteng Kecamatan Sukasari Kabupaten Sumedang. Mayoritas mata pencaharian masyarakat Desa Genteng adalah bertani. Layaknya seorang petani, untuk meningkatkan perekonomiannya maka mereka membutuhkan tanah untuk melakukan aktivitas pertaniannya. Bagi petani yang tidak memiliki lahan pertanian pribadi, mereka memanfaatkan tanah terlantar milik Perum Perhutani yang ada di kawasan hutan di sekitar tempat tinggal mereka untuk bercocok tanam. Konflik agraria ini muncul ketika Perum Perhutani berusaha mengambil alih lahan yang sedang digarap oleh petani dengan tujuan untuk melakukan konservasi hutan sebagai upaya untuk menjaga ekosistem dan kelestarian hutan. Petani yang juga merasa 


\begin{tabular}{|c|c|c|c|c|}
\hline JURNAL & \multirow{2}{*}{ VOLUME 1 } & NOMOR 2 & HALAMAN 70-141 & $\begin{array}{l}\text { ISSN 2655-8823 }(p) \\
\text { ISSN 2656-1786 }(e)\end{array}$ \\
\hline KOLABORASI RESOLUSI KONFLIK & H
\end{tabular}

memiliki hak untuk menggunakan lahan tersebut merasa dirugikan. Perbedaan kepentingan inilah yang akhirnya menyebabkan konflik agraria di Desa Genteng (Adiansah, dkk, 2019:3).

Pada dasarnya konflik tidak dapat dibiarkan dan harus dikelola dengan baik karena jika tidak, yang terjadi adalah kerugian bagi kehidupan masyarakat. Pengelolaan konflik yang terjadi di masyarakat dikenal dengan istilah manaemen konflik. Menurut Fuad \& Maskanah (2000) manajemen konflik merupakan langkah-langkah yang diambil para pelaku atau pihak ketiga dalam rangka mengarahkan perselisihan ke arah hasil tertentu yang mungkin atau tidak mungkin menghasilkan suatu akhir berupa penyelesaian konflik dan mungkin atau tidak mungkin menghasilkan ketenangan, hal positif, kreatif, bermufakat atau agresif.

Manajemen konflik pada dasarnya dapat dilakukan melalui pendekatan resolusi konflik. Resolusi konflik menurut Weitzman \& Weitzman (dalam Morton \& Coleman 2000: 197) mendefinisikan resolusi konflik sebagai sebuah tindakan pemecahan masalah bersama (solve $a$ problem together). Lain halnya dengan Fisher et al (2001:7) yang menjelaskan bahwa resolusi konflik adalah usaha menangani sebab-sebab konflik dan berusaha membangun hubungan baru yang bisa tahan lama diantara kelompokkelompok yang berseteru. Pada akhirnya setiap resolusi konflik harus mampu mendorong para pihak yang berkonflik untuk menghentikan semua tindakan perselisihan terhadap satu sama lain dan dapat saling menerima keberadaan satu sama lain (Wallensteen, 2002:8).

Resolusi konflik dapat dilakukan dengan menggunakan berbagai pendekatan. Salah satu pendekatan dalam penanganan konflik yaitu pendekatan berbasis komunitas. Menurut Haider (2009) pendekatan berbasis masyarakat/komunitas (Community Based Approach) dalam resolusi konflik yaitu suatu pendekatan yang berusaha memberdayakan kelompok dan lembaga yang berada pada level komunitas lokal dengan memberikan kontrol langsung kepada masyarakat atas pengambilan keputusan, perencanaan langkah aksi, pelaksanaan serta pemantauan, melalui proses yang menekankan partisipasi dan manajemen inklusif dari masyarakat lokal.

Pada dasarnya setiap individu atau kelompok yang terlibat dalam konflik berusaha untuk melakukan berbagai upaya resolusi konflik, termasuk pada kasus konflik agraria di Desa Genteng. Melihat konsensus yang saat ini diterapkan pada masyarakat petani di Desa Genteng sebagai hasil dari upaya resolusi konflik yang telah dilakukan sebelumnya, pada dasarnya upaya resolusi konflik tersebut salah satunya dilakukan melalui upaya resolusi konflik berbasis komunitas. Namun, berdasarkan studi literatur yang dilakukan oleh peneliti, ditemukan bahwa belum ada penelitian yang khusus mengkaji upaya resolusi konflik berbasis komunitas pada kasus konflik agraria di Desa Genteng ini.

Berdasarkan hal tersebut, kajian mengenai resolusi konflik berbasis komunitas pada kasus konflik agraria di Desa Genteng ini menjadi menarik untuk didalami lebih lanjut, oleh karena itu Pusat Studi Konflik dan Resolusi Konflik FISIP UNPAD mengadakan acara diskusi publik dengan judul Resolusi Konflik Agraria Pada Masyarakat Petani di Desa Genteng Kecamatan Sukasari Kabupaten Sumedang dengan menghadirkan tiga narasumber utama yang berasal dari masyarakat Desa Genteng yang diwakili oleh Kepala Seksi Kesejahteraan Rakyat Desa Genteng, praktisi agraria yang berasal dari Kepala Bidang Sengketa Pertanahan Badan Pertanahan Nasional Kabupaten Sumedang dan akademisi yang berasal dari Departemen Sosiologi FISIP UNPAD sekaligus sebagai peneliti di Pusat Studi Konflik dan Resolusi Konflik FISIP UNPAD. Tulisan ini akan membahas hasil diskusi publik tersebut berkaitan Resolusi Konflik Agraria Pada Masyarakat Petani di Desa Genteng Kecamatan Sukasari 


\begin{tabular}{|c|c|c|c|c|}
\hline JURNAL & \multirow{2}{*}{ VOLUME 1 } & NOMOR 2 & HALAMAN 70-141 & $\begin{array}{l}\text { ISSN 2655-8823 }(p) \\
\text { ISSN 2656-1786 }(e)\end{array}$ \\
\hline KOLABORASI RESOLUSI KONFLIK
\end{tabular}

Kabupaten Sumedang berdasarkan pandangan masyarakat lokal, praktisi dan akademisi.

\section{METODE PENELITIAN}

Penelitian ini menggunakan metode kualitatif deskriptif dengan teknik pengumpulan data menggunakan diskusi publik tentang Resolusi Konflik Agraria Pada Masyarakat Petani di Desa Genteng Kecamatan Sukasari Kabupaten Sumedang berdasarkan pandangan masyarakat lokal, praktisi dan akademisi.

\section{HASIL DAN PEMBAHASAN Hasil Penelitian}

Berikut ini akan dipaparkan hasil diskusi publik tentang Resolusi Konflik Agraria Pada Masyarakat Petani di Desa Genteng Kecamatan Sukasari Kabupaten Sumedang berdasarkan pandangan masyarakat lokal, praktisi dan akademisi.

Pandangan Masyarakat Lokal tentang Konflik Agraria di Desa Genteng

Pada tahun 2000-2010, terjadi mis komunikasi antar warga dengan pihak Perum Perhutani. Pada tahun 2000, Perum Perhutani merubah fungsi hutan produksi di Kawasan Manglayang Timur menjadi hutan lindung. Masyarakat sekitar hutan termasuk masyarakat Desa Genteng yang sebagian besar berprofesi sebagai petani merasa keberatan dengan adanya alih fungsi hutan tersebut. Sebelumnya, masyarakat sekitar hutan memanfaatkan lahan yang ada di kawasan hutan Manglayang Timur tersebut sebagai lahan untuk bercocok tanam. Jenis tanaman yang ditanam di lahan tersebut yaitu sayuran dan palawija. Adanya kebijakan alih fungsi hutan menyebabkan masyarakat tidak lagi diperbolehkan untuk bercocok tanam di kawasan tersebut. Kebijakan ini juga menyebabkan masyarakat sekitar hutan kehilangan mata pencaharian sebagai petani karena tidak adanya lahan yang dapat dimanfaatkan sebagai lahan pertanian.
Alih fungsi lahan hutan yang terjadi di Kawasan Manglayang Timur ini mendorong masyarakat Desa Genteng juga beralih profesi. Semula masyarakat yang berprofesi sebagai petani beralih menjadi pengerajin anyaman bambu atau menjadi peternak domba. Namun, ternyata penghasilan sebagai pengerajin bambu atau peternak tidak sebesar ketika menjadi petani. Masyarakat tidak dapat beralih profesi menjadi profesi lain yang lebih menguntungkan karena tidak memiliki keahlian lain. Selain itu, tingkat pendidikan masyarakat pun masih tergolong rendah. Hal ini mendorong masyarakat untuk menuntut diperbolehkannya kembali untuk menanam sayuran dan palawija di lahan kehutanan. Tuntutan dari petani ini tidak dikabulkan oleh Perum Perhutani, karena kebijakan alih fungsi hutan ini merupakan kebijakan pusat yang tidak dapat diganggu gugat. Protes terus dilakukan oleh para petani dengan didukung oleh berbagai lembaga swadaya masyarakat seperti Serikat Tani Nasional (STN), dan berbagai LSM lainnya.

Diawal tahun 2010, dibentuklah LMDH (Lembaga Masyarakat Desa Hutan) sebagai penengah antara petani dengan Perum Perhutani. LMDH berusaha untuk memediasi petani dan Perum Perhutani hingga akhirnya lahirlah kesepakatan yang memperbolehkan petani untuk menggarap kembali lahan di kawasan hutan, namun dengan jenis tanaman tertentu yang telah ditentukan oleh Perum Perhutani. Jenis tanaman tersebut yaitu tanaman kopi dan buah-buahan. Adapun tanaman sayuran boleh ditanam hanya untuk mengisi kekosongan diantara tanaman-tanaman kopi dan buah-buahan.

Setelah adanya kesepakatan tersebut, ternyata konflik tidak berhenti begitu saja. Petani yang telah terbiasa menanam sayuran dan melakukan panen antara 1-3 bulan sekali merasa keberatan untuk menanam kopi yang masa panen pertamanya harus menunggu hingga 3 tahun. Belum lagi, para petani juga tidak memiliki keterampilan dan pengetahuan 


\begin{tabular}{|c|c|c|c|c|}
\hline JURNAL & \multirow{2}{*}{ VOLUME 1 } & NOMOR 2 & HALAMAN 70-141 & $\begin{array}{l}\text { ISSN 2655-8823 }(p) \\
\text { ISSN 2656-1786 }(e)\end{array}$ \\
\hline KOLABORASI RESOLUSI KONFLIK & H
\end{tabular}

dalam penanaman kopi tersebut. Hal ini kembali mendorong petani untuk menuntut diperbolehkannya kembali menanam sayuran secara penuh. Dalam kondisi ini, Perum Perhutani berusaha untuk menahan para petani untuk menanam sayuran secara penuh dan terus melanjutkan penanaman kopi. Hingga pada akhirnya, 3 tahun berselang para petani dapat melakukan panen kopi pertama, petani tidak melanjutkan protes karena mereka dapat mulai merasakan manfaat dari penanaman kopi. Melihat keberhasilan dari penanaman kopi tersebut, para petani lain yang sebelumnya enggan menanam kopi mulai tertarik untuk menanam kopi. Hingga saat ini, tercatat terdapat 15 kelompok petani kopi di Desa Genteng yang hidup berdampingan dengan Perum Perhutani dalam kondisi yang harmonis.

\section{Pandangan Praktisi Pertanahan tentang Konflik Agraria di Kabupaten Sumedang}

Konflik berasosiasi pada perselisihan, ketidakharmonisan atau pertentangan. Kondisi paling ekstrim dari konflik yaitu adanya tindakan kekerasan. Konflik ini melibatkan dua pihak yang berseberangan satu sama lain. Berkaitan dengan konflik agraria, konflik agraria merupakan konflik pertanahan. Dalam konteks hokum tanah, agraria ini diartikan sebagai permukaan bumi (pasal 4 ayat 1, UU No. 5 Tahun 1960 tentang Peraturan Dasar Pokok-Pokok Agraria). Dalam Undang-Undang tersebut, agraria memiliki arti yang luas yaitu bumi, air dan kekayaan alam yang terkandung di dalamnya. Hukum agraria tidak mengatur satu bidang hukum saja namun merupakan kelompok bidang hukum yang saling berkaitan dengan penguasaan sumber daya alam, diantaranya mencakup tanah, kehutanan, perkebunan, air dan sumber daya alam termasuk penguasaannya.

Keberadaan lembaga pertanahan sejak diundangkannya UUPA pada tanggal 24 September 1960 telah merubah tatanan yang mendasar dalam penataan perkembangan hukum agrarian di Indonesia khususnya dalam pendaftaran tanah dalam konteks konversi maupun konteks konflik, sengketa dan perkara pertanahan. Kemudian berdasarkan UUPA tersebut, sejak berdirinya lembaga pertanahan yang saat ini bernama Kementerian Agraria dan Tata Ruang/Badan Pertanahan Nasional secara periodic terprogram tanah di seluruh wilayah Negara Kesatuan Republik Indonesia harus dapat dilaksanakan pendaftaran haknya menjadi sertifikat tanah.

Sejak pemerintahan Presiden Joko Widodo, kinerja Kementerian Agraria dan Tata Ruang/Badan Pertanahan Nasional khususnya di Kantor Pertanahan Kabupaten Sumedang, telah melangkah lebih nyata melalui Program Pendaftaran Tanah Sistematis Lengkap yang diawali pada tahun 2017 dengan menerbitkan 10.00040.000 sertifikat tanah per tahun. Pada jumlah tersebut, didalamnya terdapat tanah milik petani antara 100-500 bidang. Hal ini menunjukkan adanya keberpihakan pemerintah terhadap para petani. Selain itu, pendaftaran tanah juga dilaksanakan pada program redistribusi tanah yang merupakan salah satu resolusi konflik agraria di Kabupaten Sumedang selama kurun waktu 2016-2019 secara signifikan dilaksanakan di beberapa desa sebagai objek lokasi redistribusi tanah. Pada tahun 2016 redistribusi tanah dilakukan di Desa Jemah Kecamatan Jatigede dan di Desa Kamal Kecamatan Tanjungkerta masing-masing sebanyak 1.000 bidang tanah, serta di Desa Margalaksana Kecamatan Sumedang Selatan sebanyak 450 bidang tanah kepada 450 petani pemegang hak tanah. Pada tahun 2018, redistribusi tanah dilakukan di Desa Jemah dan Desa Cisampih Kecamatan Jatigede masing-masing sebanyak 500 bidang tanah kepada 500 petani pemegang hak tanah. Sedangakan pada tahun 2019, redistribusi tanah dilakukan di Desa Cipancar dan Desa Baginda Kecamatan Sumedang Selatan masing-masing 250 bidang tanah kepada 250 petani pemegang hak tanah. 


\begin{tabular}{|c|c|c|c|c|}
\hline JURNAL & \multirow{2}{*}{ VOLUME 1 } & NOMOR 2 & HALAMAN 70-141 & $\begin{array}{l}\text { ISSN 2655-8823 }(p) \\
\text { ISSN 2656-1786 }(e)\end{array}$ \\
\hline KOLABORASI RESOLUSI KONFLIK
\end{tabular}

Dasar hukum penanganan konflik pertanahan dilakukan berdasarkan Peraturan Menteri Agraria dan Tata Ruang/Kepala Badan Pertanahan Nasional Republik Indonesia Nomor 11 Tahun 2016 tentang Penyelesaian Kasus Pertanahan. Berdasarkan peraturan tersebut, penyelesaian kasus pertanahan dilakukan berdasarkan inisiatif dari kementerian dan pengaduan masyarakat. Beberapa kasus pertanahan yang pernah diselesaikan oleh Kantor Pertanahan Kabupaten Sumedang yaitu sengketa tanah Blok Satim dengan luas lahan 54 Hektar yang terletak di Kampung Cikeuleu Desa Sakurjaya Kecamatan Ujung Jaya. Tanah tersebut belum terdaftar dengan sesuatu hak dan digunakan sebagai area hutan jati dan jenis tanaman keras lain yang dikelola oleh Perum Perhutani Unit III Jawa Barat dan Perum Perhutani Kesatuan Pemangku Hutan Sumedang.

Tanah di Blok Sati mini diklaim oleh beberapa pihak yaitu ahli waris K.H Mukibat, Elang Casbani selaku ketua Yayasan Jaya Indra Jati Hayu, Perum Perhutani, Sultan Kasepuhan Cirebon, Ahli waris Pesantren Cikeuleu, Ahli waris Koman Sutawijaya dan Ahli waris R. Kasan Sutawijaya alias R. Kasan Djajadiningrat. Perkembangan resolusi konflik saat ini yaitu Kantor Pertanahan Kabupaten Sumedang tidak dapat melakukan putusan perkara Tata Usaha Negara No. 7/G.TUN/2005/PTUN-BDG yang telah memiliki kekuatan hukum berupa penertiban sertifikat hak milik atas tanah tersebut diatas kepada para ahli waris R. Kasan Djadjadiningrat, sehingga pihakpihak lain dinyatakan kalah.

Kasus kedua yaitu kasus konflik agraria yang terjadi di lokasi yang terkena proyek jalan tol Cisumdawu seluas 125 Hektar di Blok Ranca Baren Desa Babakan Asem Kecamatan Congeang Kabupaten Sumedang. Pihak yang terlibat dalam konflik ini yaitu penduduk Desa Babakan Asem dan Perum Perhutani. Upaya resolusi yang dilakukan oleh Kantor Pertanahan Kabupaten Sumedang yaitu melakukan rapat koordinasi, pengumpulan data dan melaksanakan zoning dengan menggunakan GPS.

Untuk kasus konflik agraria di Desa Genteng sudah bisa diselesaikan dengan cukup baik oleh pihak Perum Perhutani KPH Sumedang dan masyarakat lokal Desa Genteng dengan dimediasi oleh LMDH.

Pandangan Akademisi tentang Resolusi Konflik Agraria Berbasis Komunitas di Desa Genteng

Permasalahan konflik agraia di Desa Genteng terjadi pada tahun 2011. Konflik ini terjadi karena adanya perbedaan kepentingan dalam penggunaan lahan antara masyarakat lokal dengan Perum Perhutani. yang semula hutan produksi beralih fungsi menjadi hutan lindung. Masyarakat keberatan dengan adanya peralihan fungsi hutan tersebut, dikarenakan mata pencaharian masyarakat menjadi hilang. Perum Perhutani membuat kebijakan masyarakat boleh menggunakan lahan hutan tersebut, akan tetapi tanaman yang semula produksi sayuran diganti menjadi tanaman kopi. Dalam konflik agraria ini, berbagai pihak berupaya melalukan resolusi konflik agar konflik yang terjadi tidak terus berlanjut (Adiansah dkk. 2019).

Berdasarkan kajian literatur yang telah dilakukan pada dasarnya masalah agrarian di Desa Genteng dipengaruhi beberapa penyebab diantaranya:

a. Di tahun 2018 tentang persoalan Air dengan PDAM

Berdasarkan analisis Yunita, dkk masyarakat dalam menggunakan air kehilangan control karena adanya PDAM. Karena masalah air tersebut terjadi perubahan pola pertanian yang menyebabkan masyarakat tidak bisa mengairi lahan- lahan pertanian mereka dampaknya lahan pertanian mereka menjadi kering Aliran air yang diberikan PDAM ke masyarakat hanya cukup untuk keperluan MCK bagi sekitar 700 jiwa di dusun Cisitu dan hanya 


\begin{tabular}{|c|c|c|c|c|}
\hline JURNAL & \multirow{2}{*}{ VOLUME 1 } & \multirow{2}{*}{ NOMOR 2 } & HALAMAN 70-141 & $\begin{array}{l}\text { ISSN 2655-8823 }(p) \\
\text { ISSN 2656-1786 }(e)\end{array}$ \\
\hline
\end{tabular}

mengairi sekitar 20 hektar lahan pertanian dari 280 hektar.

b. Potensi Kehilangan kerja

Hilangnya kontrol terhadap sumber air sama saja dengan kehilangan basis produksi material masyarakat desa. Masalah tersebut menyebabkan terjadinya perubahan pola pertanian, mata pencaharian, relasi social serta struktur social masyarakat. potensi kehilangan pekerjaan pada masyarakat desa akan sangat terlihat. Disisi lain, tingkat pendidikan masyarakat relative rendah juga menyulitkan masyarakat untuk mendapatkan pekerjaan yang layak. (Yunita, dkk 2018)

c. Lahan

- Konflik yang terjadi diakibatkan oleh perbedaan kepentingan lahan antara petani Desa Genteng dengan Perhutani

- Petani menginginkan lahan Perhutani dikelola, khususnya pengelolaan secara intensif yang melatarbelakangi oleh motif ekonomi.

- Berbeda dengan perhutani, mereka ingin menjaga hutan agar tetap lestari demi generasi yang akan datang. Perhutani juga tidak ingin kerusakan hutan yang ada di Timur Manglayang semakin rusak karena bisa berdampak ke bencana alam, seperti banjir atau erosi tanah.

- Konflik yang terjadi di Desa Genteng sudah terjadi sejak tahun 1982. Konflik yang ada berlangsung secara damai dan ada juga yang berujung pada kerusuhan. (Andri Paranginangina, 2013)

- Konflik yang terjadi didesa terjadi karena adanya perbedaan kepentingan dalam hal pemanfaatan lahan kehutanan antara masyarakat dengan Perum Perhutani, selain konflik ini juga terjadi adanya ketidaksamaan, ketidakadilan dan ketidaksetaraan, konflik social yang terjadi dimasyarakat pada dasarnya merupakan respon yang tidak terhidarkan dari adanya ketidaksetaraan tersebut.

- Konflik agraria yang terjadi di Desa Genteng terjadi pada multiple system dari sistem mikro, mezzo, maupun makro.

d. Kemiskinan

Jumlah penduduk Desa Genteng tercatat sekitar 6.500 jiwa dan mata pencarian warga didomisili oleh petani dan buruh tani. Akibat terbatasnya ekonomi, sedikitnya 500 kepala keluarga (KK) di Desa Genteng Kecamatan Sukasari, Kabupaten Sumedang Jawa Barat belum menikmati aliran listrik.

e. Rendahnya kesadaran masyarakat dalam pelestarian lingkungan.

Masyarakat belum memiliki kesadaran akan pentingnya menjaga pelestarian lingkungan hidup atas dasar hasil kegiatan perekonomian masyarakat sehingga memungkinkan terjadinya kesinambungan antara kegiatan perekonomian masyarakat dengan pelestarian lingkungan hidup (Nurliana dkk, 2017)

f. Kesulitan pemasaran kopi Mitra tidak mampu memasarkan secara maksimal hasil kopi, kendala yang dirasakan yaitu kemasan produk yang kurang memadai.

Untuk mengatasi berbagai masalah terkait dengan pertanahan tersebut, terdapat beberapa cara yang telah dilakukan oleh berbagai pihak yaitu:

- Pemberian hak tanah yang ditelantarkan oleh Perum Perhutani kepada masyarakat dengan perlindungan hukum melalui hukum Preventif dan Represif. 


\begin{tabular}{|c|c|c|c|c|}
\hline JURNAL & \multirow{2}{*}{ VOLUME 1 } & NOMOR 2 & HALAMAN 70-141 & $\begin{array}{l}\text { ISSN 2655-8823 }(p) \\
\text { ISSN 2656-1786 }(e)\end{array}$ \\
\hline KOLABORASI RESOLUSI KONFLIK & HALA \\
\hline
\end{tabular}

- Dibentuknya consensus baru dimasyarakat dengan diperbolehkannya para petani melakukan aktivitas pertanian di lahan kehutanan namun dengan jenis tanaman tertentu yaitu tanaman kopi

- Dibentuk integrasi social (Integration) yaitu Perum Perhutani memperbolehkan masyarakat untuk melakukan aktivitas pertanian dilahan tersebut, dengan catatan ditanami jenis tanaman tertentu.

- Petani Desa Genteng membutuhkan lahan garapan untuk digunakan masyarakatnya bertani. Tanaman apa selain sayur yang dapat dipanen dalam waktu enam bulan lamanya, sehingga kopi dapat tetap ditanami namun petani juga tetap dapat melakukan kegiatannya guna mendapatkan pendapatan.

- Pemanfaatan sumber air secara bersama antara masyarakat desa dengan PDAM diharapkan mampu membangun dan menciptakan prinsip keadilan bersama dan integrasi sosial.

- Program pengabdian masyarakat melalui kegiatan pelatihan pemberdayaan petani kopi melalui penguatan kapasitas dalam pengelolaan hasil kopi di Desa Genteng, Kecamatan Sukasari Kabupaten Sumedang (Nurliana dkk, 2017)

Agar upaya penyelesaian konflik agraria di Desa Genteng ini dapat menghasilkan dampak yang maksimal, maka dapat dilakukan upaya resolusi konflik berbasis pemberdayaan masyarakat sebagai berikut:

a. Lahan dan kemiskinan dua sisi yang penuh polemik dan dinamika (Hutan Produksi- Hutan Lindung)

b. Pengembangan komoditas ekonomi baru selain kopi dan sayuran adalah prioritas utama

c. Rekonsiliasi konflik melalui pemberdayaan masyarakat adalah tiang utama. d. Kesadaran masyarakat untuk membangun bersama adalah pondasi utama (kejujuran dan gotong royong)

e. Modal sosial adalah hal yang paling utama (kelompok perekat, menjembatani- relasi luas)

f. Rekonsiliasi konflik adalah persamaan persepsi dalam interaksi social- lingkungan "Bahasa" yang baik adalah inti interaksi sosial.

\section{KESIMPULAN}

Berdasarkan pembahasan yang telah diuraikan dimuka, maka terdapat beberapa kesimpulan, diantaranya yaitu:

a. Terjadi mis komunikasi antar warga Desa Genteng dengan pihak Perum Perhutani dalam pemanfaatan lahan.

b. Alih fungsi lahan hutan yang terjadi di Kawasan Manglayang Timur mendorong masyarakat Desa Genteng juga beralih profesi.

c. Dalam upaya resolusi konflik, LMDH (Lembaga Masyarakat Desa Hutan) memiliki peran yang sangat penting yaitu sebagai penengah antara petani dengan Perum Perhutani.

d. Mediasi yang dilakukan oleh LMDH menghasilkan sebuah konsensus baru yaitu Perhutani memperbolehkan petani lokal untuk menggarap kembali lahan di kawasan hutan, namun dengan jenis tanaman tertentu yang telah ditentukan oleh Perum Perhutani.

e. Dalam upaya meminimalisir konflik agraria, BPN melakukan upaya sertifikasi tanah dan redistribusi tanah terutama di wilayah rawan konflik agraria yaitu di lokasi pembangunan bendungan Jatigede, dan lokasi pembangunan tol Cisumdawu.

f. Masalah yang terjadi di Desa Genteng tidak hanya sekedar konflik pemanfaatan lahan saja, namun juga lebih kompleks dari itu seperti pengelolaan air PDAM, 


\begin{tabular}{|c|c|c|c|c|}
\hline JURNAL & \multirow{2}{*}{ VOLUME 1 } & NOMOR 2 & HALAMAN 70-141 & $\begin{array}{l}\text { ISSN 2655-8823 }(p) \\
\text { ISSN 2656-1786 }(e)\end{array}$ \\
\hline KOLABORASI RESOLUSI KONFLIK
\end{tabular}

potensi kehilangan pekerjaan, konflik lahan, kemiskinan, kesadaran dalam pelestarian lingkungan, kesulitan pemasaran hasil pertanian.

g. Upaya pemecahan masalah di Desa Genteng telah dilakukan oleh berbagai pihak yang dilakukan melalui upaya hukum preventif dan represif, pembentukan konsensus baru, pembentukan integrasi sosial dan kerjasama dengan perguruan tinggi melalui program pengabdian kepada masyarakat.

h. Upaya penyelesaian konflik dan pemecahan masalah yang ada di Desa Genteng salah satunya dapat dilakukan melalui pemberdayaan masyarakat.

\section{DAFTAR PUSTAKA}

Adiansah, Wandi, Apsari, Nurliana Cipta \& Raharjo, Santoso Tri. (2019). Resolusi Konflik Agraria di Desa Genteng Kecamatan Sukasari Kabupaten Sumedang. Jurnal Kolaborasi Resolusi Konflik Vol. 1 No. 1 Januari Tahun 2019.

Dahrendorf, Ralf. (1959). Class and Class Conflict in Industrial Societies. Stanford: Stanford University Press.

Fisher, Simon, dkk. (2001). Mengelola Konflik: Keterampilan \& Strategi Untuk Bertindak. Jakarta: The British Council.

Fuad, H.F. \& Maskanah, S. (2000). Inovasi Penyelesaian Sengketa Pengelolaan Sumber Daya Hutan. Bogor: Pustaka Latin.

George Ritzer, Douglas J. Goodman. (2010). Teori Sosiologi Modern. Jakarta: Kencana.

Haider, Huma. (2009). Community-based Approaches to Peacebuilding in Conflict-affected and Fragile Contexts. Governance and Social Development Resource Center. University of Birmingham.
Konsorsium Pembaruan Agraria. (2017). Catatan Akhir Tahun 2017 Konsorsium Pembaruan Agraria: Reforma Agraria di Bawah Bayangan Investasi-Gaung Besar di Pinggiran Jalan. Jakarta: KPA. Morton \& Coleman. (2000). The Handbook of Conflict Resolution. Illinois: Waveland Press Inc.

Nulhaqim, Soni Akhmad., Irfan, Maulana., Harding, Diana., Jatnika, Dyana Chusnulita. (2017). Konflik Sosial Di Kampung Nelayan: Studi Kasus di Pantai Utara Kota Cirebon, Jawa Barat. Jurnal Sosiokonsepsia Kementerian Sosial Republik Indonesia Volume 6 Nomor 2 Januari-April 2017.

Putra, Bagus Ani. (2013). Peran kearifan lokal dalam resolusi konflik keyakinan beragama di Jawa Timur. Jurnal Masyarakat, Kebudayaan dan Politik Volume 26 Nomor 1 Tahun 2013, Halaman 1-14.

Putra, Said Hidayat, Turrintoro, Astuti, Puji. (2014). Faktor Determinan Konflik Agraria Di Desa Setrojenar Kecamatan Bulus pesantren Kabupaten Kebumen. Jurnal Ilmu Pemerintahan, Volume 1, No. 1, Tahun 2014.

Undang-Undang Republik Indonesia Nomor 5 Tahun 1960 tentang PokokPokok Agraria.

Undang-Undang Republik Indonesia Nomor 7 Tahun 2012 tentang Penanganan Konflik Sosial.

Wallensteen, Peter. (2002). Understanding Conflict Resolution: War, Peace and the Global System. London: SAGE Publications.

Yunita, Desi, Sagita, Novie Indrawati \& Humaedi, Sahadi. (2018). Perubahan Sosial Pada Masyarakat Desa: Tinjauan Materialisme Budaya dari Pemanfaatan Bersama Mata Air Pada Era Revolusi Industri 4.0. Proceeding - Open Society Conference 2018: Social and Political Challenges in Industrial 4.0. 